\title{
CDISC SDTM Ebola Virus Findings About Test Code Terminology
}

National Cancer Institute

\section{Source}

National Cancer Institute. CDISC SDTM Ebola Virus Findings About Test Code

Terminology. NCI Thesaurus. Code C132316.

Terminology associated with the Ebola virus findings about test code codelist of the Clinical Data Interchange Standards Consortium (CDISC) Study Data Tabulation Model (SDTM). 